\title{
Foreword
}

\section{Louis-Philippe Rochon}

I first met Marc Lavoie in the Fall of 1986. I was an undergraduate student in economics, at the University of Ottawa, where Marc had been teaching since 1979. At that time, economics was only a secondary passion of mine. My primary focus was politics and Political Science, given my active involvement in politics. In fact, my major was Political Science, and economics was my minor. Any interest in economics was only to serve my overall political goals.

To be honest, my interest in economics was slow to develop, firstly because I thought it was a rather dry and boring subject, and secondly, because I was rather skeptical about what I was being taught in the introductory classes (both reasons are certainly related!). I always doubted, among a very long list of examples, that prices were a pure market phenomenon determined by the mysterious forces of supply and demand.

As silly as it may sound, I remember the game Trivial Pursuit being all the craze in the early 1980s. I wanted to buy it but the game was sold out everywhere. I prepaid for one, and was placed on a long waiting list. But the price of the game never changed: it remained the same despite the insane demand for it. I remember asking one of my professors why the price was not increasing, and he quickly drew a standard diagram, of shifting demand and supply curves on the blackboard as an explanation of the 'stickiness' of the price. But I remained unconvinced by the answer.

Overall, I had difficulty in accepting free market ideology, the existence of an auctioneer, or some shortcomings with respect to the actions of the State, as I was always a proponent of more State and fiscal activism. But I never had the proper tools, diagrams, or theories to formulate an adequate response, let alone a formal critique. I was equipped with intuition, but these were shot down every time I brought them up in class. I remember clearly one time being in the office of my second year macro professor, who knew of my political activism. We would have many discussions, and he once told me that my political judgment clouded my economic thinking. As a result, I slept-walked through my economic courses.

But that would all change a few years later. In fact, all my intuitions and questions were answered when I enrolled in Marc's course in the Fall of 1986, ECO 4514: Théorie postkeynésienne: monnaie et demande effective (Post-Keynesian Theory: Money and Effective Demand). The course seemed to offer me the answers I was looking for: finally, I had the arguments to criticize economics! For the record, that course was the basis for Marc's 1992 book, so those who have read the book will surely identify with the experience I had taking the class.

Now, my enrolment in that course was actually the result of scheduling desperation. I remember the difficulties in fitting a fifth class in my schedule. But I remember even more the advice of many students who told me to stay away from 'that class'. In the end, Marc's class was the only one that fit my desired schedule; so despite the advice of my fellow students, I enrolled. It proved to be a very good decision: the course was a true revelation. All the nagging 
doubts I had about economics were answered. And it was at that time that I knew I wanted to study economics: I quickly changed my major to economics, and political science became my minor.

In that class, we had to make a presentation, as well as write an essay on the characteristics of post-Keynesian economics. I remember Marc very much liking my presentation. At the time, I was also taking a class in 'Political Thought' with André Vachet. We had spent a few weeks discussing 'le choc des idées' - a popular expression in French that translates into English as 'the clash of ideas'. For me, this was what Marc's class was all about: a shock! This is especially true since I was being taught in other classes that 'there were no alternatives': a kind of 'this is economics' take-it or leave-it attitude. This said, there were other heterodox professors in that department, like Mario Seccareccia, Jacques Henry and Alain Parguez, but before 1986, I had not had them as professors yet. I would only have them in the Spring of 1987.

With respect to the essay, it reflected my presentation on the clash of ideas and how postKeynesian economics was an alternative to the dominant view, and on how this class 'shocked' me, and represented a change and a way forward. It was all wonderful and Marc appreciated it, but in the end, he wanted an essay on 'post-Keynesian' economics: endogenous money, mark-up pricing, etc. My essay was probably more suitable for a philosophy class.

But Marc's class, and the subsequent Spring classes, were a revelation and had a profound impact on me and, as the saying goes, I never looked back. I found the answers to all those questions and doubts I had about economics. Suddenly, economics was no longer boring: it was not simply about free markets, but institutions, motivations, uncertainty, social classes, and more. This was more aligned with what I was thinking about the role of the State and how it could benefit society as a whole - ideas that are still with me today. Economics made sense. Over the years, I have remained close to Marc and his writings, and Marc was in fact my unofficial thesis director while I was at the New School. To my knowledge, in fact, it was the first time Marc had been on any external doctoral thesis committee.

\section{Post-Keynesian monetary theory: selected essays}

It has almost been thirty-five years since I first took Marc's class, during which time I have come to read probably everything he has written (mea culpa, probably not his work in sports economics!). I have also been honored to publish many of his articles (of which two appear here: Lavoie, 2003 (Chapter 4, this volume) and 2010 (Chapter 7, this volume)). But recently, I have come to realize that some younger scholars are less aware of some of these earlier articles. Of course, they all know his 1992 and 2014 books, and his book with Godley (Godley and Lavoie, 2007). But I felt there was a need to bring together some older articles, many which have influenced my own thinking.

I first approached Marc three years ago or so with the idea of making a collection of some of his articles on credit, money and endogenous money. He initially rejected the idea. But anyone who knows me knows I don't easily back down. So I approached him again in early 2019, at which time he finally agreed, and I began the process of collecting clean copies of the articles and the painful job of getting authorizations from publishers!

I confess that every single article in this book has influenced me profoundly. I learned endogenous money through these writings, but also through many conversations I had with Marc over the years. But there are a few articles that for me stand out. 
His article in Jarsulic's 1985 book (Chapter 3, this volume) was certainly one that I remember reading many times over. I remember how startled I was in reading the opening paragraph and his warning of '[following] Keynes too closely' (ibid., p. 63) on matters related to money. This is something that I would appreciate only much later, as I have also come to the same conclusion. And his suggestion to go 'beyond Keynes' would also apply to all aspects of macroeconomics, not just money.

Through Marc, I read Kaldor and Eichner, the latter being a much underappreciated scholar and widely unknown by younger heterodox authors today (see Lavoie, 1991 (Chapter 5, this volume); and the book we edited with Mario Seccareccia on Eichner; see Lavoie, Rochon and Seccareccia, 2010). I remember Eichner's 1985 article (also in Jarsulic's book) being on the reading list in Marc's class (see Forman, Groves and Eichner, 1985). In fact, for years I thought Eichner's contribution was foremost to monetary and macroeconomic theory. It is only later I discovered his microeconomic work on mark-up pricing!

Then there were two important articles, both in 1996. First, his Money in Motion ${ }^{1}$ article (Chapter 8, this volume) was instrumental in making clear the role of monetary policy and the nature of the rate of interest as a distributional variable. That article, which I recommend to students every time I have the opportunity, contains all the elements for a deep criticism of mainstream policy. In fact, my 'go-to' quote is the following:

It then becomes clear that monetary policy should not so much be designed to control the level of activity, but rather to find the level of interest rates that will be proper for the economy from a distribution point of view. The aim of such a policy should be to minimize conflict over the income shares, in the hope of simultaneously keeping inflation low and activity high. (ibid., p. 536)

To this day, that sentence remains at the heart of my approach to monetary policy.

Second, Marc's article in the Scottish Journal of Political Economy has held up very well two decades later, and remains in my view the best analysis of the horizontalist/structuralist debates (Chapter 9, this volume). It made clear so many issues for me, and was instrumental in writing my dissertation and book, which dealt with many of these issues (see Rochon, 1999).

Finally, Marc's ‘A Primer on Endogenous Credit-Money' (published in a book I co-edited with my longtime collaborator, Sergio Rossi; see Lavoie, 2003, Chapter 4, this volume) is a step by step analysis of money's endogeneity under different conditions. In each case, Marc carefully demonstrates through the use of T-accounts, the central essence of money's endogeneity. It is an article I also encourage everyone to read, and cannot overestimate its value, not only as an article on endogenous money but also for its important contribution to pedagogy.

\section{Concluding thoughts}

My story of how I became a post-Keynesian is not unique. I have heard many times from students all over the world how post-Keynesian economics reinvigorated their passion for economics, and how they also found it boring until they discovered post-Keynesian theory. More often than not, students have told me specifically how this happened through discovering papers or books written by Marc. This was a driving force for bringing together these papers. As Marc says in the introduction to this book, these older papers often contain overlooked 
gems, and as such serve a great purpose over and above, say, his remarkable 1992 and 2014 books.

I am grateful to Marc for having accepted to publish this collection of papers. I am convinced students and young scholars will benefit as much from them as I have.

\section{Note}

1. When I arrived at the New School in 1993, I asked Edward Nell within days of my arrival if there was a project on which I could work. He pointed to a bunch of papers scattered on a side desk in his office. He told me it needed to come out as a book. A few students had tried before but no one could finish the task, and gave up. So off I went. It took me a good year to comb through all those articles, but eventually I triumphed and the 760-page book Money in Motion did come out in 1996.

\section{References}

Deleplace, G. and E. Nell (1996) (eds), Money in Motion: The Post-Keynesian and Circulation Approaches, London: Palgrave.

Forman, L., M. Groves and A. Eichner (1985), 'The Demand Curve for Money Further Reconsidered', in M. Jarsulic (ed.), Money and the Macro Policy, Boston: Kluwer Nijkoff.

Godley, W. and M. Lavoie (2007), Monetary Economics: An Integrated Approach to Credit, Money, Income, Production and Wealth, London: Palgrave MacMillan.

Lavoie, M. (1992), Foundations of Post-Keynesian Economics Economic Analysis, Aldershot, UK and Brookfield, VT, USA: Edward Elgar Publishing.

Lavoie, M. (2014), Post-Keynesian Economics: New Foundation, Cheltenham, UK and Northampton, MA, USA: Edward Elgar Publishing.

Lavoie, M., L.-P. Rochon and M. Seccareccia (2010) (eds), Money and Macroeconomic Issues: Alfred Eichner and Post-Keynesian Economics, Armonk, NJ: M.E. Sharpe.

Rochon, L.-P. (1999), Credit, Money and Production: An Alternative Post-Keynesian Approach, Cheltenham, UK and Northampton, MA, USA: Edward Elgar Publishing. 